\title{
Characterizing Industrial Design Education in Turkey: A Current Synthesis for Future Directions
}

\author{
Derya IRKDAŞ DOĞU *, Şebnem TIMUR ÖĞÜT **, H. Alpay ER***
}

\section{Abstract}

In recent years, we see an expansion of schools offering degrees at different levels in the field of industrial design in Turkey. Reasons for this expansion can well be found outside the design field itself as well as the national education reforms. This shift towards corporatization of universities is a business model usually adapted from foreign models. This adoption in education models also lead to the expansion of industrial design programs especially in private universities. Despite the rapid growth of industrial design education in Turkey, there is relatively little knowledge about the features or qualities that serve to identify these design departments. The main aim of this article is to discuss characteristics of industrial design departments in Turkey as a case regarding programs' profiles in geographical distribution, housing universities and faculties, academic members, student selection criteria and student numbers. Final remarks are recommendations for a prospective state of design education in Turkey.

Keywords: Industrial Design, Design Education, University Degrees, Design Departments, Turkey.

\section{Türkiye’de Endüstriyel Tasarım Eğitimini Tanımlamak: Güncel Bir Sentez ve Gelecek için Öneriler \\ Özet}

Türkiye'de endüstriyel tasarım alanında farklı düzeylerde eğitim veren üniversitelerin sayılarında son yıllarda bir artış gözlemlenmektedir. Bu artışın nedenleri Türkiye'deki eğitim reformlarından kaynaklanmamakla birlikte, tasarım alanı dışındaki gelişmelerde bulunabilir. Üniversitelerin şirketleşme yolundaki evrimi genellikle yabancı modellerden uyarlanmış bir iş modelini takip eder niteliktedir. Benzer eğitim modellerinin benimsenmesi endüstriyel tasarım programlarında da, özellikle özel üniversitelerin bünyesinde, genişleme yolunda yönlendirici olmaktadır. Türkiye'de hızla büyümekte olan endüstriyel tasarım eğitimi çerçevesinde ise tasarım departmanlarını tanımlayıcı hizmet özellikleri veya nitelikleri hakkında nispeten az bilgi bulunmaktadır. Bu makalenin temel amacı, Türkiye'de endüstriyel tasarım bölümlerinin özelliklerini; coğrafi dağııımı, ev sahibi üniversiteler ve fakülteler, akademik kadrolar, öğrenci seçme kriterleri ve öğrenci sayılarına referansla tartışmaktır. Türkiye'de tasarım eğitiminin ileriki vadede durumuna dair öneriler ayrıca sunulmaktadır.

Anahtar Sözcülkler: Endüstriyel Tasarım, Eğitim, Üniversite Dereceleri, Ulusal Bölümler, Türkiye. 


\section{Introduction}

In the past few years industrial design education has become an inclusive subject where the general landscape is changing ever so rapidly. Today, a central concern for the value and quality of industrial design education offered at university level is considered to outgrow within the field itself. However, the problem of rapid expansion that design education faces today can well be found outside the field. This shift towards the corporatization of universities as a business model can also be regarded as a representation of many social and economic problems of present circumstances that trigger the growth of private universities. Especially in the field of industrial design education the number of private universities is well above the ones of the public universities. Consequently, it is valuable to explore the similarities and differences within the broader framework of design education in universities today.

The objective of this article is to provide fundamental information to identify the characteristics of industrial design education and its current state. The data used for synthesis is from the inventory of all industrial design departments in Turkey. Quantitative analysis methods are used to analyze and compare the department profiles and their positions based on information and rankings published in the department catalogues, department websites and in reports published by the Higher Education Council. An overall quantitative evaluation in design departments is also included to render the structural status of academic staff at a sub-organizational level. Final remarks are recommendations for a prospective state of design education in Turkey.

\section{Methodology}

The purpose of this research is to identify the development of industrial design education over the organizational structures of industrial design departments in Turkey. The challenges of research for comparison of industrial design education in different contexts consider different levels of methods to map similarities and differences. Dimmock (2007: 285) proposes the "cultural and cross-cultural comparative method" approach to compare the performance of educational organizations in different settings. A cultural approach to comparative study of industrial design departments is applicable at multiple levels as; sub-organizational, organizational, local, regional, national and beyond (Dimmock \& Walker, 1998). In this study the structural-functionalist model is used, where education systems are fractured into structures. This model is analytical but is limited to explain the extent of the process (Dimmock, 2007: 285).

In respect to quantitative analysis, this study develops a conceptual framework for cross-comparative analysis; and scales the data into visualized graphics for quantitative investigation on a national level. The purpose of quantitative study is to use numerical data gathered from departments to describe the relationships between the variables as a confirmatory (Fairbrother, 2007: 40-42). The data sources are accessed through the department web pages and published materials (books, magazines, articles) over a three year period from 2011 to 2014, which constitute parts of the exploratory research in this study. In cases of incomplete sources, alternatives and supplements (often from oral and written evidence) serve the particular purpose (Sweeting, 2007: 160). For this study, to supplement incomplete sources, members from industrial design departments were contacted either through e-mail, phone or interview sessions. The first phase of the case study was the organization of the data sources into a data matrix, where in the second phase it was converted into a case narrative.

\section{A Brief History of Design Education in Turkey}

A brief introduction to the history of industrial design education is necessary to understand the dynamics of the establishment of design education in a historical context. In that sense, this introductory section provides a brief historical review of educational development of industrial design. During the 1950s, there has been a growing demand in the number of students applying to higher education institutions (ÖSYM, 2006: 35), result- 
ing with the establishment of four state universities ${ }^{1}$ with an Anglo-American education model in Turkey (Mizıkacl, 2006: 16).

The fifties were significant with the early attempts in the development of industrial design as it emerged as a technical assistance program for crafts and design to be realized by Peter Muller-Munk Associates assigned by the US government (Er, Korkut, \& Er, 2003: 22, 23, 26, 27). Although this initiative was not realized, some of the high ranked members of the Ministry of Education prepared a report about the foreign, especially German, schools of design, and proposed the establishment of a similar type of school in the mid fifties. Prof. Ing. Adolf G. Schneck from the Stuttgart Academy of Fine Arts was assigned to develop a feasibility report prior to the opening of such a school. His research was developed according to the needs of the period and the Turkish state, proposing a school with five departments (Celbiş, 2006: 34).

In 1957, the State School of Applied Fine Arts (Devlet Tatbiki Güzel Sanatlar Yüksek Okulu, DTGSYO) was founded in Istanbul with the financial support of the Ministry of Education and the first academic members were assigned from both Germany and Turkey (Celbiş, 2006; Er, 2001: 128). The school was the first to introduce 'basic design' education that was an extension of the Bauhaus education model developed by Prof. Ing. Adolf G. Schneck (Celbiş, 2006: 34; Şatır, 2006: 22). Education at DTGSYO was so successful that it also helped promote the first initiative to propose an industrial design (endüstriyel dizayn) department by 1965 . However, specialization on industrial design was offered as a discipline, also referred to as a shadow program, within the interior architecture department during the seventies (Celbiş, 2006: 35).

The following periods through the 1960s and the 1970s was the expansion of Anglo-American and Continental European university models (Mızıkacı, 2006: 16) and a growing concern of fair access to higher education programs (ÖSYM, 2006: 35). However, this period was significant with the military coup that took place in 1960.
The effects were huge on the industry with an import substitution that limited the development of industrial design. The tendency towards product design was merely formed around the copying of foreign products ( $E r, 2009$ : 76-77). The initiatives towards industrial design education by a small group of architects, interior and ceramics designers did not take place until the end of the sixties at institutions in Istanbul and Ankara (Er, 2009: 77). In 1969, Prof. David K. Munro was assigned to METU for three years with the support of Agency for International Development (AID) to organize and plan educational activities of the industrial design department (Asatekin, 1979, 2006: 29; Er et al., 2003: 30). However, as it was later stated by the schools' rector Kemal Kurdaş that it was unavailable to provide necessary conditions of the day to realize an industrial design department (Asatekin, 2006: 28).

The seventies had been a period for development, which placed Turkey amongst the newly industrialized countries as the industry started to emerge with diversity (Er, 2009: 78-79). However, early industrial design education in Turkey was not established for an industrial necessity. Celbiş (2006: 36-37) criticizes the relation between education and practice as a problematic one as he states; "Design education looks like it is programmed for an idealized industry and economic relations." However, it was really an early initiative of a few visionary people, who followed developments in western education (Celbiş, 2006: 36-37; Er, 2009: 77). Seventies in that sense have also been an emerging era for industrial design education.

An opportunity presented itself when a private school, School of Applied Industrial Arts (Uygulamalı Endüstri Sanatları Yüksek Okulu, UESYO) was assigned to the Academy to be governed with the new regulation in 1971. The same year, the first industrial design program was established within the interior design department in UESYO (Küçükerman, 2011: 14; 'MSÜ Endüstri Ürünleri Tasarımı Bölümü', 1998: 36). The following year with the new regulation private schools were conjoined to state universities and the Academy became the new Faculty of Architecture at İstanbul State Academy of Fine Arts 
('2006-2007 Öğretim Yılı Kurumsal Öz Değerlendirme Raporu', 2008: 4; Küçükerman, 2011: 19, 20).

In 1979, an industrial design program had finally been realized in METU under the architecture faculty. Although the main aim was to start a masters' degree program the university administration was in favor of an undergraduate program (Asatekin, 2006: 28; Er et al., 2003: 31, 32). The dean of the faculty at that time, Mustafa Pultar, assigned Mehmet Asatekin and Güner Mutaf to work on the industrial design program. Asatekin was a state scholar in Italy, who later visited some design schools in England and Holland, while Mutaf studied design in Denmark. Asatekin and Mutaf prepared a report about industrial design in general and its specific state in Turkey, which was later prepared as a booklet and presented to the university administration (Asatekin, 2006: 29). The report included a detailed curriculum of a four-year undergraduate program with course descriptions and information about the teaching staff, student numbers, and hardware and structural requirements (Asatekin \& Mutaf, 1978).

Graduates who were sent to study abroad were also coming back to take part in the new educational developments (Celbiş, 2006: 35). DTGSYO, industrial product design discipline became a major degree offered at an undergraduate level in the 'Furniture - Interior Architecture' department between 1977 and 1984. The Industrial Product Design department was officially founded after DTGSYO was conjoined to the Marmara University, as the Faculty of Fine Arts, in the 1984-85 academic year. After the department was founded the students were awarded the degree of industrial product design (Alyanak, 1996; Celbiş, 2006: 36).

In 1982, establishing a new industrial design department was also on the agenda of İstanbul Technical University (ITU). A committee of five academic members, Nigan Bayazıt, Nihat Toydemir, Mete Ünügür, Filiz Özer and Ahmet Alphan were selected on a voluntary basis to organize the initiation process. The committee prepared a syllabus for the 1984-85 academic year. However, the initiation process was interrupted when Bayazit went abroad for her academic studies. In 1989, ITU started industrial design education on a masters' level. The decision to convert from a full four year undergraduate program to a two year masters' degree was reasoned simply because it would be easier and less risky (Ertaş, 2011: 52-54). Only after four years, undergraduate degree was offered with Nihat Toydemir as the department head (Bayazit, 2006: 49) and the first students were selected according to an aptitude test. In 1995, selection criteria for students were changed to the central examination system (Ertaş, 2011: 60).

\section{Institutionalization of Industrial Design Education}

Design education was entering a new phase with the establishment of the Council of Higher Education (YÖK) in 1981. YÖK was a single national quality agency for a single and centralized national assessment system for higher education and was set up by the government according to Decree Law Nr. 2547. This new centralized system restructured all institutions as universities and undergraduate admission criteria in higher education institutions was subject to a selection system organized by YÖK, Student Selection and Placement Center (ÖSYM). However, aptitude tests (special skills examination) were also valid for some degrees in art and design fields (ÖSYM, 2006).

Until 1981, higher education institutions were categorized as universities, academies, vocational schools and teacher training institutes. While the universities were self-governed but were funded by the government, the others were self-funded and were under the authority of the Ministry of Education. This new system also allowed non-profit foundations to establish private higher education institutes under the supervision of the YöK (Mızıkacl, 2006: 17-18). However, it can be said that the year 1982 is the milestone of industrial design education as YÖK started to regulate and control universities' policies including academic organization of the faculty and departments and academic promotion requirements (Er \& Er, 2006: 88). The second military coup in 1980 changed the political and economical character of Turkey radically. 
After the 1980s, the open foreign trade economy policies and privatization allowed Turkey to start exporting national goods. However, the policies did not support neither competitiveness nor manufacturing. Before the mid nineties, modernization was the main driving force for the development of industrial design. However, this modernization was a realization as a cultural modernity project in the first phase. After the establishment of the customs union between the European Union and Turkey in 1996, the local market started to compete against the European market (Er, 2009: 79-84). The recognition of industrial design in local industry became significantly visible and debatable (Celbiş, 2006: 37).

The rapid expansion of industrial design departments took off significantly after 1995 and with a second breaking point after 2004. Between 1971 and 1994, there were only four departments within the state universities in Turkey. The total number of departments reached 25 with a significant 525\% growth rate in the period from 1995 to 2014 (Figure 1). In 1995, a new masters' degree was offered at a state university, İzmir Institute of Technology, and was later followed by two new undergraduate degrees at private universities at Yeditepe University in 1996 and at Kadir Has University in 1997.

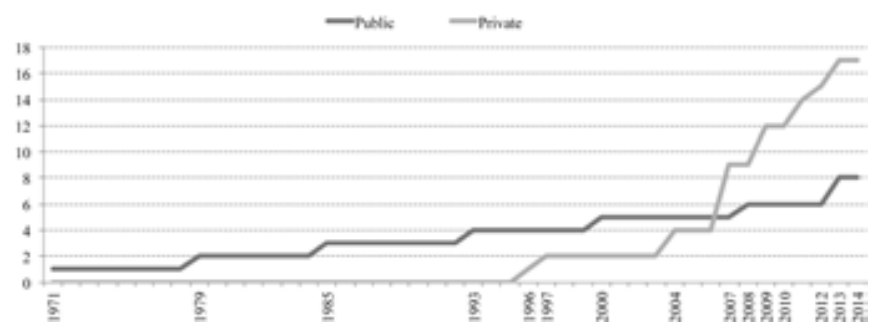

Figure 1. Expansion of industrial design departments between 1971 and 2014.

In the 2001 financial crisis, the Turkish domestic market collapsed, which led the new growing market to export goods. As a strategy to overcome this period companies started to use design as a tool for survival. Turkish Exporters Assembly (TIM) has forced the government to form a design support program for textile and clothing industries in 2003. The same year TIM had an approach to help found the Design Council of Turkey in collaboration with Industrial Designers' Society of Turkey (ETMK) and the current industrial design schools. However, this approach was only realized in 2009 with the support of the Turkish Patent Institute. In 2008, TIM also took part in the organization of a national design award scheme with ETMK (Er, 2009: 86-89). This phase is the turning point for design as it was recognized by the industry as an important topic for the first time in Turkish history (Celbiş, 2006: 37). On the education front, this period is also important with the introduction of new design schools (Er, 2009: 84).

An early attempt towards the internationalization of higher education in Turkey dates back to 1997 with the Lisbon Recognition Agreement between the European Council, UNESCO and Turkey, followed by the Bologna Process ${ }^{2}$ in 1999. Finally in 2000, the EU Lisbon Strategy as the first credit system was introduced. In 2006, National Qualifications Framework for Higher Education in Turkey (NQFHETR) was launched by the YÖK. However, the approval of the NQF-HETR was not realized until 2009. By the beginning of 2011, four pilot universities were chosen to fully adapt and update their programs according to the Bologna criteria by the end of the same year. The remaining universities were scheduled to complete the adaptation process by the end of 2012 ('Türkiye Yükseköğretim Yeterlilikler Çerçevesi (TYYÇ)', 2011). The structural changes that are introduced with Bologna have been in two areas as; the structure of YÖK and the promotion of vocational education. The latter topic deals with the establishment of vocational programs allowing students to enter vocational schools without an exam and proceed to a bachelor's degree program if desired (Mızıkacı, 2006: 61).

This implementation and promotion of vocational programs effected industrial design programs to a certain degree. In 2008, the first Industrial Product Design program was introduced at Pazaryeri Vocational High School at Bilecik University. The following year, another program was offered at Çorlu Vocational High School at Namık Kemal University. In 2013, three more schools; Hacettepe Ankara Sanayi Odası 1st OSB Vocational High School, 
Plato Vocational High School and Tosya Vocational High School were established. However, there has been no enrollment to Pazaryeri Vocational High School since the foundation year. The latter schools have announced quota for 185 students for 2013-14 academic year, which is $23 \%$ of the total number of positions offered by all industrial design departments at university level. ${ }^{3}$

\section{Inventory of Industrial Design Departments in Turkey}

The typology of higher education institutions is mainly public universities in Turkey. Currently there are 185 universities in total, 109 of which are state and 76 are private universities (YÖK, 2015). The distribution of industrial design departments that are housed within 25 universities, of which 9 are state and 16 are private, means $64 \%$ of the departments are run at private universities that are privately funded. Figure 2 below, shows the distribution of public and private institutions and the distribution of industrial design Bachelor Degrees offered in Turkey, respectively.

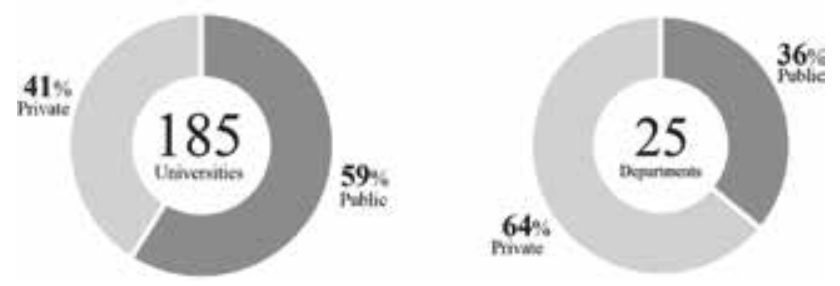

Figure 2. Distribution of public and private universities (left), and industrial design departments in Turkey (right).

The state universities offering a bachelors' degree in industrial design are represented within the $36 \%$ of the overall universities as a minority group, whereas the majority of universities are private. This is contrary to the overall distribution of higher education institutions in Turkey, which is dominated by public universities.

The geographic distribution of the universities offering degrees in industrial design (Figure 3) are mainly located in Istanbul of the Marmara region with sixteen universities, thirteen of which are private and the remaining three public. The remaining universities are lo- cated in Ankara (3) of the Central Anatolia region, Izmir (3) of the Aegean region, Karabük (1) of the Black Sea region, Eskişehir (1), Konya (1) and Kayseri (1) of the Central Anatolia region.

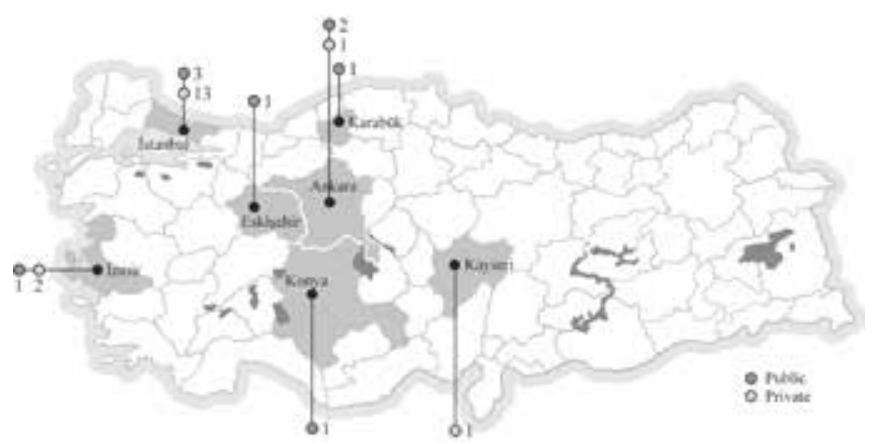

Figure 3. Geographical distribution of industrial design departments in state and private universities in Turkey.

Other than the locational imbalances, there is also the financial autonomy of the institutions. One of the major difficulties state universities struggle with is the limited budgeting system. This insufficient funding affects the quality of education in public universities and slows the adaptation process to changing conditions such as; physical space, and technological improvement for teaching and learning materials. Private universities on the other hand have different funding structures that are independent from state sources (YÖK, 2007).

Funding is an important factor in education, especially for design education, where physical requirements such as; studios, workshops, computer labs as well as non-physical requirements technological improvements for design software licensing are well above any other specialization outside the field of design. This may be one of the reasons for the dominance of design faculties within private universities. Moreover, competition is strengthened by the transfer of academic staff towards private ones, who are emeritus members of public universities.

As of 2014 , there are a total number of 25 undergraduate level degrees offered both in state and private funded universities. Industrial design departments are located 


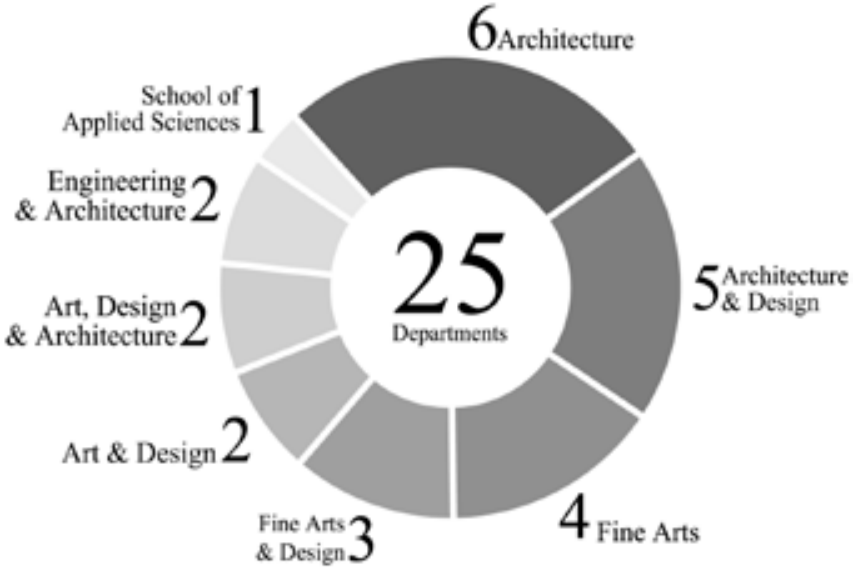

Figure 4. Distribution of industrial design departments according to faculty types.

within different faculties (Figure 4) with a majority in architecture (6) followed by architecture and design (5); fine arts (4); fine arts and design (3); art and design (2); art, design and architecture (2); engineering and architecture (2); and school of applied sciences (1).

Faculty types are usually effective on an interdisciplinary level for undergraduate degrees as students are introduced to a number of elective courses offered in other departments of the housing faculty. A full list of all industrial design departments is illustrated in Table 1 consisting of the foundation years for each degree, level of degree offered, acceptance criteria for undergraduate degree and student quotas.

\subsection{Acceptance Criteria and Student Numbers}

Higher education institutions are subject to a selection system organized by YÖK, Student Selection and Placement Center (ÖSYM). However, aptitude tests (special skills examination) are also valid for some degrees in art and design fields (ÖSYM, 2006). In the field of industrial design, we can see both types of selection criteria for a bachelor's degree. The aptitude test (AT) is performed individually by each department to evaluate candidates' skill levels to an expected degree and therefore is characteristic to each department. Currently there are eight universities, MSGSU, MU, Yeditepe, Doğuş, Haliç, Atılım, Beykent, and Atılım, using the AT for entrance qualification criteria.1 The other type is the common entrance examination conducted by ÖSYM, which evaluates students' test results on a national level. For a qualification in industrial design degree candidates are measured ac-

\begin{tabular}{|c|c|c|c|c|c|c|c|c|}
\hline \multirow[b]{2}{*}{ UNTVERSITY } & \multirow[b]{2}{*}{ TYPE } & \multirow{2}{*}{$\begin{array}{l}\text { FACULTY/SCHOOL/ } \\
\text { INSTITUTE }\end{array}$} & \multirow[b]{2}{*}{ DEPARTMENT } & \multicolumn{3}{|c|}{ FOUNDATION YEAR } & \multirow{2}{*}{$\begin{array}{c}\text { ACCEPTANCE } \\
\text { CRITERIA }\end{array}$} & \multirow{2}{*}{$\begin{array}{c}\text { STUDENT } \\
\text { QUOTA } \\
\text { OSYM } \\
2013-14\end{array}$} \\
\hline & & & & $\begin{array}{l}\text { Under- } \\
\text { graduate }\end{array}$ & Graduate & Doctoral & & \\
\hline Mima Sinan Fine Arts Uaiversity & State & Architecture & Indeatrial Prodoct Design & 1971 & 1982 & 1982 & $A \mathrm{~T}$ & 30 \\
\hline Middle East Technical University & State & Architecture & Indestrial Design & 1979 & 1997 & 2004 & $\mathrm{MF}-4$ & 45 \\
\hline Marmara University & State & Fine Arts & Indestrial Product Design & 1985 & 1986 & 1992 & $\mathbf{A T}$ & 20 \\
\hline Istanbul Technical University & State & Architecture & Indestrial Product Design & 1993 & 1989 & 1996 & $\mathrm{MF}-4$ & 45 \\
\hline Irmir Institute of Technology & State & Architecture & Industrial Design & . & 1995 & . & . & \\
\hline Yeditepe University & Private & Fine Arts & Industrial Design & 1996 & . & . & AT & so \\
\hline Kadir Has University & Private & Art and Desiga & Industrial Design & 1997 & 2009 & $\cdot$ & $\mathrm{MF}-4$ & 30 \\
\hline Anadolu Univensity & State & Architecture and Design & Indestrial Design & 2000 & 2002 & . & $\mathrm{MF}-4$ & 60 \\
\hline Izmir University of Economics & Private & Fine Arts and Design & Industrial Design & 2004 & 2006 & 2013 & $\mathrm{MF}-4$ & 30 \\
\hline Doguy University & Private & Fine Arts and Design & Industrial Product Design & 2004 & $\cdot$ & $\cdot$ & AT & 25 \\
\hline Okan Univensity & Private & Fine Arts & Indeatrial Product Design & 2007 & - & - & MF-4 & 30 \\
\hline Haliç University & Private & Architecture & Indtatrial Design & 2007 & - & - & AT & 26 \\
\hline Lạk University & Private & Architecture and Design & Indtatrial Design & 2007 & - & - & MF-4 & 30 \\
\hline $\begin{array}{l}\text { TOBB University of Ecosomics and } \\
\text { Technology }\end{array}$ & Private & Art, Design and Architecture & Industrial Product Design & 2007 & 2014 & $\cdot$ & $\mathrm{MF}-4$ & 30 \\
\hline Gazi University & Sente & Architecture & Indestrial Prodoct Design & 2007 & 2013 & 2013 & $\mathrm{MF}-4$ & 25 \\
\hline Eastern Mediterranean University & State & Architecture & Indestrial Product Design & $2008-12$ & - & $\cdot$ & - & \\
\hline Bahçesehir University & Private & Architecture and Design & Indestrial Design & 2009 & $\cdot$ & $\cdot$ & MF-4 & 44 \\
\hline Athlim University & Private & Art, Design and Architecture & Industrial Product Design & 2009 & - & $\cdot$ & AT & 30 \\
\hline Melikşah University & Private & Engineering and Architecture & Industrial Product Design & 2010 & $\cdot$ & $\cdot$ & $\mathrm{MF}-4$ & 25 \\
\hline Yapar University & Private & Art and Design & Industrial Design & 2010 & - & - & $\mathrm{MF} \rightarrow$ & 22 \\
\hline Istanbul Arel University & Private & Engineering and Architecture & Induatrial Product Design & 2010 & . & . & $\mathrm{MF}-4$ & 24 \\
\hline Istanbul Bilgi University & Private & Architecture & Industrial Product Design & 2012 & * & . & $\mathrm{MF}-4$ & so \\
\hline Beykent University & Private & School of Applied Sciences & Industrial Product Desige & 2012 & $\cdot$ & $\cdot$ & AT & 70 \\
\hline Istanbal Aydin University & Private & Architecture and Design & Indestrial Product Desige & 2013 & $\cdot$ & $\cdot$ & AT & 60 \\
\hline Selcuk University & State & Fine Arts & Indeatrial Product Desige & 2013 & $\cdot$ & $\cdot$ & MF-4 & 10 \\
\hline Karabük Uhiversity & State & $\begin{array}{l}\text { Safranbolu Fethi Toker Fine } \\
\text { Arts and Design }\end{array}$ & Industrial Product Design & 2013 & $\cdot$ & - & $\mathrm{MF}-4$ & 66 \\
\hline Ózyegin University & Private & Architecture and Design & Indeatrial Product Desige & 2013 & 2014 & 2014 & MF-4 & 26 \\
\hline
\end{tabular}

Table 1: List of Industrial Design Departments \& 2013-14 Statistics. 
cording to their test scores in mathematics and science on a level of fourth degree (MF-4).

The distribution of AT and MF- 4 student numbers are equally balanced with the number of schools that offer a degree in industrial design. The total number of students qualified by AT for 2014-15 academic year is 311 students, which represents the $34 \%$ of the overall number of positions offered in eight departments. The remaining $66 \%$ represents 592 students, who are assigned through the centralized system to the remaining seventeen departments.

Although, there are different views on the selection criteria, MF- 4 students are considered to have more knowledge in areas of mathematics and science, whereas AT students are equipped with higher artistic skill sets. The conflict here lies within the centralized system, where students' choice may not be their first preference for a future career. However, with AT the student's selection criteria may lay on two different grounds. First would be a positive approach, where we may assume that the student has a clear career and school selection. Second is a negative approach, where a student may prefer to take AT if s/he has not scored successfully to be replaced by ÖSYM criteria. However, in the second approach the departments' criteria for selecting high skilled students becomes a major determinant. In both scenarios, it would be most beneficial to conduct a research with graduates to map out their career choices and see how many of the students carry on with an industrial design or design related professions. This would also help inform and orient prospective students, who are entering industrial design departments through the central examination system for an adequate selection of their education for a possible future career.

\subsection{Graduate Degrees}

Graduate degrees in industrial design are offered on master (11) and doctoral2 (7) levels. The first master's and doctoral programs were offered by Mimar Sinan Fine Arts University in 1982. Shortly after the establishment of the first post graduate programs Marmara University started its master's program in 1986, followed by the doctoral degree program in 1992. Istanbul Technical University first started off with a graduate master's degree program in 1989 and established the undergraduate degree in 1993 and the doctoral degree in 1996. Izmir Institute of Technology is the final school to offer a master's degree during the nineties.

The gradual increase in postgraduate degrees starts in the early 2000s with Anadolu University offering master's degree in 2002, followed by İzmir University of Economics3 offering master's degree in 2006 and doctoral degree in 2013. Gazi University has established both master's and doctoral degree programs again in 2013. TOBB University of Economics and Technology on master's level and Özyeğin University on both master's and doctoral levels offer most recent degrees in 2014. Currently there are eleven master's degree programs available in six state and five private universities. Universities offering a master's degree represent only $31 \%$ of the overall universities offering a bachelor's degree. Doctoral degree programs are even less available at only $22 \%$ of the overall universities, with four state and three private universities, meaning only less than one quarter of the universities are offering a post graduate degree. If the expansion of industrial design education continues at a similar rate there will be a growing demand for academic members qualified to take position for future departments, who are preferably from the field of industrial design or design related fields. In order to sustain the required number of academic staff, more schools must offer postgraduate degrees in industrial design. Currently, students enrolled in existing postgraduate degrees are increasing. However, there is limited number of academic staff qualified (holding a Ph.D. degree) to undertake graduate students in existing graduate programs.

\subsection{Academic Staff}

Number of academic staff according to their positions in the departments is represented in the following table below. In public universities academic members holding 
a Ph.D. degree, awarded titles with and above assistant professorship, are categorized as academic members, while the rest are categorized as instructors. Both category members hold a tenure position in public universities, while members of private universities hold a non-tenure position and are recruited on a contract basis. represent less than half of all members with a Ph.D. degree. Amongst the instructors there are seven members with a Ph.D., who do not hold a tenure position. There is a considerable number of research assistants (70) studying on master's and doctoral levels with a majority from METU as a result of the lecturer placement program, ÖYP.4

\begin{tabular}{|c|c|c|c|c|}
\hline University / Position & $\begin{array}{l}\text { Academic } \\
\text { Member }\end{array}$ & Instructor & $\begin{array}{l}\text { Research } \\
\text { Assistant }\end{array}$ & $\begin{array}{l}\text { Part-time } \\
\text { instructor }\end{array}$ \\
\hline Mimar Sinan Fine Arts University & 10 & 1 & 5 & 16 \\
\hline Middle East Technical University & 9 & 6 & 20 & 20 \\
\hline Marmara University & 6 & 2 & 3 & - \\
\hline Istanbul Technical University & 8 & 4 & 6 & 24 \\
\hline Izmir Institute of Technology & 5 & 4 & 7 & - \\
\hline Yeditepe University & 5 & 1 & - & 14 \\
\hline Kadir Has University & 4 & 1 & 1 & 9 \\
\hline Anadolu University & 2 & 5 & 7 & - \\
\hline Izmir University of Economics & 3 & 5 & 3 & 9 \\
\hline Doğuş University & 3 & 3 & - & 5 \\
\hline Okan University & 1 & 1 & 3 & - \\
\hline Haliç University & 3 & 1 & 1 & 12 \\
\hline Işık University & 2 & 2 & 1 & 8 \\
\hline TOBB University of Economics and Technology & 5 & 1 & 1 & 11 \\
\hline Gazi University & 6 & 2 & 11 & 3 \\
\hline Eastern Mediterranean University & 1 & - & - & 3 \\
\hline Bahçeşehir University & 4 & 1 & 2 & 8 \\
\hline Attlım University & 3 & 2 & 1 & 7 \\
\hline Melikşah University & 2 & 3 & 1 & 6 \\
\hline Yaşar University & 3 & 1 & 2 & 8 \\
\hline Istanbul Arel University & 3 & 2 & - & 7 \\
\hline Istanbul Bilgi University & 3 & 2 & 2 & 15 \\
\hline Beykent University & 4 & 2 & 1 & 1 \\
\hline İstanbul Aydın University & 4 & - & - & - \\
\hline Selçuk University & 3 & 1 & 1 & - \\
\hline Karabük University & 4 & 1 & 2 & - \\
\hline Özyeğin University & 5 & - & 1 & 2 \\
\hline TOTAL & 111 & 54 & 70 & 188 \\
\hline
\end{tabular}

Table 2: Distribution of academic members at industrial design departments in Turkey, 2014.

Total number of academic members (111) is twice as much as instructors (54). Members with an academic title of Professor Dr. (26) and Associate Prof. Dr. (19) combined
However, this number does not represent all students, who are enrolled to a graduate degree. Some of the students are holding non-academic positions or are either unemployed. 
Total number of academic staff (235) including members, instructors and assistant are slightly over the total number of part-time instructors (188). Part-time instructors are emeritus or current academic members, from other departments, faculties or universities, and professional designers. This can be interpreted in several ways. First, working with professionals is valuable for students to learn from practicing designers. Furthermore, current members teaching as part-time instructors at other universities create a unifying link and act as mediator for knowledge transfer. Finally, emeritus members are included in the education, providing invaluable contribution with extent knowledge and experience. In public universities emeritus cannot hold an academic membership. Many emeritus members are recruited in private universities, where they usually act as the founder or the facilitator. This transfer of human capital is also effective in the adoption of education models in newly establishing departments. Usually, such a case is valuable and in favor of private schools.

On the other hand, the number of academic members in total is considerably small when compared to other European and North American universities. Academic staff at each department is required to deliver courses on an undergraduate and graduate degree. So, it is quite a challenge for members to educate students from both levels. This is limiting in several perspectives particularly as the number of graduate students for each advisor is inadequately high especially for the early-established degree programs in state universities.

\section{Conclusion}

The provision of industrial design education offered at undergraduate and graduate degrees in Turkey profits in the account of the universities and the value of the design field. It is evident that conditions for the development of industrial design education in a historical perspective are not necessarily prevalent with the development of the local economy. However, the economic value of design is a service visible to government bodies and companies in the changing circumstances of today. Data presented according to a set of denominators in the previous parts suggests the various characteristics of the industrial design departments as follows.

In the present transitional stage of education, the number of universities offering degrees in industrial design shows that there is a growing interest for the industrial design profession. Today, the majority of the departments are housed in private funded universities. Distribution of schools throughout Turkey does not fully represent the cultural background and the regional historical design heritage that can be adopted to create an economic value by teaching these design capabilities. The geographical distribution of industrial design departments still represents a minority group, focusing mainly in İstanbul, Ankara and İzmir. On the contrary, the amount of positions advertised for industrial design degree are growing at a constant rate, especially for undergraduate degrees, which encourages more private funded universities to engage in this development. However, the quality and eligibility of education offered in newly established universities are a major concern.

A similar concern is also valid for academic staff, who either lack professional background or qualifications to teach postgraduate courses in design related degrees. The overall number of academic members with a doctoral degree is relatively low and even lower for professor and associate professor degrees when compared to the overall majority of the field. Other members from non-design related fields, although few, are usually from engineering backgrounds and are assigned to administrative positions, such as heading the department, usually for their academic rankings. Existing and future candidates of academic staff, from within and outside the field, can be encouraged to develop joint courses between local and foreign schools, which would also bring a new phase of learning and updating one's knowledge about design related topics as well as design pedagogy. Such initiatives would also encourage members from other fields to contribute more to industrial design education and research 
on interdisciplinary and multidisciplinary grounds. After all, design itself is changing and adapting around a multidisciplinary perspective.

Although the contextual analysis of curricular structures and pedagogical frameworks of departments are not discussed here, the characteristics of the academic staff and the university are the major factors concerning the structural status and development of educational programs. Therefore it is substantial to build all the services first on a sub-organizational level to achieve an equally qualified education model in Turkey. Prospective changes in design education call for a systematic planning of an effective industrial design education at different levels in Turkey to achieve a degree of quality and a general standard to meet the relative merits of international approaches.

\section{Endnotes}

1 Karadeniz Technical University and Ege University were established in 1955, followed by Middle East Technical University in 1956 and Atatürk University in 1957 (Mızıkacl, 2006).

2 The Bologna Declaration report (1999) briefly explains the importance of education for European Union and its citizens as a medium to adapt the higher education systems to the changing needs of the daily life. The design curricula are rearranged according to the European Credit Transfer and Accumulation System (ECTS) credits to be compatible with the EU education models and to pertain the Bologna process. Bologna curricular structure supports a diverse possibility for the student to choose courses, which are outside of their major areas to support the interdisciplinary attitudes towards education. However, adapting to the Bologna curricula system to promote more elective courses decrease the length and frequency of major courses ("The Bologna Declaration," 1999).

3 Data retrieved from YÖK Üniversite Listesi (2013).

4 The lecturer placement program (ÖYP) is a government regulation for the assignment of research assistants to state and private universities (YÖK, 2008).

\section{Bibliography}

(2008). 2006-2007 Öğretim Yılı Kurumsal Öz Değerlendirme Raporu, İstanbul: Mimar Sinan Güzel Sanatlar Üniversitesi.

Alyanak, Şermin (1996). “E.Ü.T. Mezunları Listesi”, Industrial Design Department Archives, Kadıköy, İstanbul: Marmara University.

Asatekin, Mehmet (1979). “Türkiye'de Endüstriyel Tasarımının Geliştirilmesi”, Arkitekt (1): 84.

Asatekin, Mehmet (2006). “ODTÜ Mimarlık Fakültesi Endüstri Ürünleri Tasarımı Bölümü ‘BAŞLANGIÇ NOTLARI’”, Tasarım + Kuram (5): 28-33.

Asatekin, M., and Mutaf, G. (1978). Endüstri Tasarımı Bölümü Kuruluş Raporu, Ankara: Orta Doğu Teknik Üniversitesi.

Bayazıt, Nigan (2006). “iTÜ>de Endüstri Ürünleri Tasarımı Bölümü ‘DENEYI’mim’”, Tasarım + Kuram (5): 41-53.

Celbiş, Ümit (2006). “Marmara Üniversitesi, Güzel Sanatlar Fakültesi, Endüstri Ürünleri Tasarımı Bölümü”, Tasarım + Kuram (5): 34-40.

Dimmock, Clive (2007). “Comparing Educational Organizations”, Comparative Education Research: Approaches and Methods, ed. Mark Bray - Bob Adamson - Mark Mason, Comparative Education Research Centre, The University of Hong Kong, Hong Kong, China: Springer, pp: 283-298.

Dimmock, C., \& Walker, A. (1998). “Towards Comparative Educational Administration: The Case for a Cross-Cultural, School-Based approach", Journal of Educational Administration 36 (4): 379-401.

Er, Alpay (2001). "The Advantage or Disadvantage of Delay? Peculiar Characteristics of Industrial Design Education in the Periphery", Designing Designers - Training Strategies for the Third Millennium, ed. Luisa Collina - Giuliano Simonelli, Milano: Edizioni POLI.DESIGN, pp: 127-134.

Er, Alpay (2009). "A Creative Convergence of Modernity, Globalization and Tradition: Understanding Industrial Design in Turkey", Asia Design Journal 4(4): 68-89.

Er, Alpay, and Er, Özlem (2006). "Design research in the periphery: A review of the foundations and development characteristics of industrial design research in Turkey", A/Z ITU Journal of the Faculty of Architecture 3(1-2): 85-97.

Er, A., Korkut, F., and Er, O. (2003). “U.S. Involvement in the development of Design in the Periphery: The Case History of Industrial Design Education in Turkey, 1950s-1970s", Design Issues 19(2): 17-34. 
Ertaş, G. Demet (2011). “iтÜ Endüstri Ürünleri Tasarımı Bölümünün Kuruluşu”, Endüstride Tasarımda Eğitimde 40 Yıl Sempozyum Bildiri Kitabı, ed. Oğuz Bayrakçı - Ahmet Z. Turan - Ilgım Eroğlu - Kerem Özcan - Sema Bıyıklığlu - A. Selami Çifter - Yener Altınparmakoğulları - Merve Özyurt - Erhan Gülen, Fındıklı, İstanbul: Mimar Sinan Güzel Sanatlar Üniversitesi, pp. 51-62.

Fairbrother, P. Gregory (2007). "Quantitative and Qualitative Approaches to Comparative Education”, Comparative Education Research: Approaches and Methods, ed. Mark Bray - Bob Adamson - Mark Mason, Comparative Education Research Centre, The University of Hong Kong, Hong Kong, China: Springer, pp. 39-62.

Küçükerman, Önder (2011). “Endüstri Tasarımı Eğitiminin 40. Yılı ve Türk Tasarımının Dört Aşaması”, Endüstride Tasarımda Eğitimde 40 Yıl Sempozyum Bildiri Kitabı, ed. Oğuz Bayrakçı - Ahmet Z. Turan - Ilgım Eroğlu - Kerem Özcan - Sema Bıyıkıığlu - A. Selami Çifter - Yener Altınparmakoğulları Merve Özyurt - Erhan Gülen, Fındıklı, İstanbul: Mimar Sinan Güzel Sanatlar Üniversitesi, pp. 13-28.

Mızıkacı, Fatma (2006). Higher Education in Turkey, Bucharest: CEPES-UNESCO.

(1998). “MSÜ Endüstri Ürünleri Tasarımı Bölümü”, Nesnel 1. Türkiye'de Tasarım Eğitimi, In H. Alpay Er - Fatma Korkut Özlem Er, İstanbul: Boyut Yayın Grubu, pp. 36-41.

Şatır, Seçil (2006). "German Werkkunstschules and the Establishment of Industrial Design Education in Turkey", Design Issues 22(3): 18-28.

Sweeting, Anthony (2007). “Comparing Times”, Comparative Education Research: Approaches and Methods, ed. Mark Bray - Bob Adamson - Mark Mason, Comparative Education Research Centre, The University of Hong Kong, Hong Kong, China: Springer, pp. 145-164.

YÖK (2008). Öğretim Üyesi Dışındaki Öğretim Elemanı Kadrolarına Naklen veya Açıktan Yapılacak Atamalarda Uygulanacak Merkezi Sınav ile Giriş Sınavlarına İlişkin Usul ve Esaslar Hakkında Yönetmelik. (26953). Ankara: T.C. Resmi Gazete.

\section{Internet Resources}

(1999). The Bologna Declaration. http://www.bologna-bergen2005.no/Docs/00-Main_ doc/990719BOLOGNA_DECLARATION.PDF (11.05.2011)

ÖSYM. (2006). Selection and Placement of Students in Higher Education Institutions in Turkey, (5): pp. 35. http://www.osym. gov.tr (04.01.2012)
YÖK (2007). Türkiye'nin Yükseköğretim Stratejisi. http://www.yok. gov.tr/documents/10279/30217/yok_strateji_ kitabi/27077070-cb13-4870-aba1-6742db37696b (08.01.2014)

YÖK (2011). Türkiye Yükseköğretim Yeterlilikler Çerçevesi (TYYÇ). http://tyyc.yok.gov.tr/ (12.11.2012)

YÖK (2013). Üniversite Listesi. https://faaliyet.yok.gov.tr/KATALOG/raporlar/ tumUnversitelereAitlletisimBilgileri.zul?raporTipi=xls (18.08.2013) 